\title{
The glyceraldehyde-3-phosphate dehydrogenase of Clostridium acetobutylicum: isolation and purification of the enzyme, and sequencing and localization of the gap gene within a cluster of other glycolytic genes
}

\author{
Wiebke Schreiber and Peter Dürre
}

Mikrobiologie und Biotechnologie, Universităt Ulm, D-89069 Ulm, Germany
Author for correspondence: Peter Dürre. Tel: +4973150 22710. Fax: +497315022719. e-mail : peter.duerre $(a$ biologie.uni-ulm.de

Keywords: GAPDH, glycolytic gene cluster, Clostridium acetobutylicum

\section{INTRODUCTION}

Clostridium acetobutylicum is an obligately anaerobic, Gram-positive, spore-forming bacterium which is characterized by a biphasic fermentation pattern. A typical butyric acid fermentation is carried out during the exponential-growth phase with acetate and butyrate as main fermentation products from starch or glucose. At the end of exponential growth, a metabolic transition to the production of organic solvents (acetone, butanol) takes place (Jones \& Woods, 1986; Dürre, 1998). During the solventogenic growth phase, glycolytic reactions are most important for energy conservation in this organism, leading to a net production of two moles of ATP per mole of hexose consumed. In contrast to genes of

Abbreviations: GAPDH, glyceraldehyde-3-phosphate dehydrogenase; PGK, phosphoglycerate kinase; PGM, phosphoglycerate mutase; PGM(i), 2,3-bisphosphoglycerate-independent phosphoglycerate mutase; TPI, triosephosphate isomerase.

The GenBank accession number for the sequence reported in this paper is AF043386. enzymes involved in solvento- and acidogenesis, only limited information is availaible about the structure and organization of genes encoding glycolytic enzymes in C. acetobutylicum. So far, only the $p f k$ (phosphofructokinase) gene has been cloned and sequenced. Adjacent to $p f k$, the pyruvate kinase gene $(p y k)$ has been identified and it was shown that the two genes are organized within a single operon (Belouski et al., 1998). One key enzyme controlling glycolytic activity is the $\mathrm{NAD}^{+}$. dependent glyceraldehyde-3-phosphate dehydrogenase (GAPDH, EC 1.2.1.12) catalysing the reversible phosphorylation of glyceraldehyde 3-phosphate to 1,3-bisphosphoglycerate. GAPDH is inhibited by a high intracellular NADH/NAD ${ }^{+}$ratio (Girbal \& Soucaille, 1994), which would otherwise favour the biotechnologically desired butanol production.

In this study, the purification of the clostridial $\mathrm{NAD}^{+}$ dependent GAPDH is presented. Cloning of the respective gene revealed a clustering with further genes $(t p i, p g k, p g m(\mathrm{i}))$ encoding enzymes catalysing sequential reactions in the Embden-Meyerhof-Parnas pathway of glycolysis. Detailed knowledge of GAPDH and its 
corresponding gene will offer the opportunity of constructing tailor-made strains that allow high glycolytic flux at high NADH concentrations and thus enhanced butanol production.

\section{METHODS}

Bacterial strains, plasmids and growth conditions. C. acetobutylicum DSM 792 (Deutsche Sammlung von Mikroorganismen und Zellkulturen, Braunschweig, Germany) was grown under strictly anaerobic conditions at $37^{\circ} \mathrm{C}$ in clostridial basal medium (O'Brien \& Morris, 1971). Continuous culture experiments were performed as described by Bahl et al. (1982) and were carried out in a Biostat B fermenter (Braun) with a working volume of 81 . Clostridium pasteurianum DSM 525 was grown under anaerobic conditions in yeast/glucose medium (101 mM glucose, $1 \%$ yeast extract, $200 \mathrm{mM}$ $\left.\mathrm{CaCO}_{3}\right)$. Escherichia coli was cultivated aerobically at $37^{\circ} \mathrm{C}$ in LB medium (Sambrook et al., 1989) supplemented with ampicillin $\left(100 \mu \mathrm{g} \mathrm{ml}^{-1}\right)$ when required.

Functional complementation experiments were performed with the E. coli gap mutant W3CG (Ganter \& Plückthun, 1990), in which this gene was inactivated by transposon $\mathrm{Tn} 10$ insertion. The mutant was cultured at $37^{\circ} \mathrm{C}$ in M63 medium (Silhavy et al., 1984) supplemented with malate or succinate $(0.4 \%, \mathrm{w} / \mathrm{v})$, glycerol $(0.1 \%, \mathrm{v} / \mathrm{v})$ and tetracycline $(20 \mu \mathrm{g}$ $\mathrm{ml}^{-1}$ ). In screening experiments for functional complementation, bacteria were grown in M63 medium plus glucose or LB medium supplemented with tetracycline and ampicillin.

Preparation of cell extracts. Anaerobic conditions were maintained throughout the whole procedure. Culture aliquots $(6 \mathrm{1})$ were removed from the continuous culture of $C$. acetobutylicum under sterile and strictly anaerobic conditions, employing tightly sealing centrifuge bottles and an anaerobic cabinet (Mecaplex). After harvesting, the cells were washed once in $1 / 100 \cdot 1 \mathrm{M}$ potassium phosphate buffer with $5 \mathrm{mM} 2$ mercaptoethanol $(\mathrm{pH} 7 \cdot 4)$. The cell pellet was suspended in $1 / 100$ buffer, supplemented with DNase I $\left(0 \cdot 1 \mathrm{mg} \mathrm{ml}^{-1}\right)$ and incubated for $30-60 \mathrm{~min}$ at $37^{\circ} \mathrm{C}$. Lysis was achieved by $3-5$ passages through a French pressure cell at $170 \mathrm{MPa}$. Cell debris was removed by centrifugation at $40000 \mathrm{~g}$ for $1 \mathrm{~h}$ at $4{ }^{\circ} \mathrm{C}$. The clear supernatant (crude extract) was used immediately or stored at $-70^{\circ} \mathrm{C}$.

Enzyme assays. The activity of GAPDH was determined spectrophotometrically at $30^{\circ} \mathrm{C}$ by monitoring the generation of NADH (physiological direction, oxidation of glyceraldehyde 3-phosphate in the presence of sodium arsenate according to Ganter \& Plückthun (1990) at $365 \mathrm{~nm}$. A coupled assay in which aldolase cleaves fructose 1,6-bisphosphate to dihydroxyacetone phosphate and glyceraldehyde 3-phosphate and the latter product serves as actual substrate, was usually used during enzyme purification (Lovitt $e t$ al., 1988). One unit of enzyme activity was defined as the amount of enzyme required to form $1 \mu \mathrm{mol} \mathrm{NADH} \mathrm{min}{ }^{-1}$.

Purification of GAPDH. If not otherwise noted, all steps were performed at $4-8{ }^{\circ} \mathrm{C}$. As a first purification step, a $50-90 \%$ $\left(\mathrm{NH}_{4}\right)_{2} \mathrm{SO}_{4}$ fractionation was carried out. The precipitated material was dissolved in $20 \mathrm{mM}$ BTP (Bistrispropane) buffer (pH 6.5) containing $1 \mathrm{mM}$ EDTA, $2 \mathrm{mM}$ DTT and $5 \%$ glycerol and applied onto a gel filtration column (Superdex 200 preparatory grade; Amersham Pharmacia Biotech) equilibrated with the same buffer. The active fractions were pooled and concentrated if necessary using Diaflo chambers and YM or PM membranes (Amicon). The protein solution was then applied to a Q-Sepharose HP column (C26/60; Amersham Pharmacia Biotech) equilibrated with BTP buffer. After the column had been washed with the same buffer, GAPDH was eluted with 5 column volumes of a linearly increasing $\mathrm{NaCl}$ gradient from 0 to $0.25 \mathrm{M} \mathrm{NaCl}$ in BTP buffer. For further experiments, the protein solution was desalted using PD10 columns according to the manufacturer's instructions (Amersham Pharmacia Biotech).

Protein concentrations were determined by the dye-binding method of Bradford (1976) using bovine serum albumin as a standard.

Gel electrophoresis. PAGE was performed using the Laemmli buffer system (Laemmli, 1970). The purity and the molecular mass of the subunits of GAPDH were examined under denaturing conditions with SDS-polyacrylamide gels. For calibration, standard proteins in the range $14-98 \mathrm{kDa}$ (Silver Stain SDS-PAGE Standards, Low Range; Bio-Rad) were used. Non-denaturing linear gradient gels $(4-27.5 \%)$ were used to estimate the molecular mass of the native enzyme. Molecular mass standards in the range $67-660 \mathrm{kDa}$ (HMW Calibration kit; Amersham Pharmacia Biotech) were used. Proteins in gels were silver-stained by the method of Blum et al. (1987).

Nucleic acid isolation and manipulation. Isolation of $C$. acetobutylicum and C. pasteurianum chromosomal DNA was performed according to Bertram \& Dürre (1989). Plasmid isolation from E. coli was done with the Qiagen Midi kit (Qiagen). DNA was manipulated by standard procedures (Sambrook et al., 1989). Enzymes were purchased from commercial suppliers and reactions were carried out under the recommended conditions.

PCR. PCR amplifications were performed as described earlier (Treuner-Lange et al., 1997). Synthetic oligonucleotides for PCR and sequencing reactions were prepared by a Gene Assembler Plus (Amersham Pharmacia Biotech) or purchased from commercial suppliers. The following primers were used for PCR amplification of a gap gene fragment of $C$. pasteurianum: 5'-GCTATTAATGGTTTTGGAAGAAT-3' (sense primer) and 5'-TGTGATCCATCAACATCTACAAT 3' (antisense primer). These oligonucleotides correspond to the DNA sequence (GenBank accession number X72219) at positions $163-185$ and $1061-1039$.

Genomic libraries of C. acetobutylicum. A HindIII genomic library of strain DSM 792 (Sauer et al., 1994) and another genomic library which resulted from partial digestion with Sau3AI and ligation into pEcoR252 (Fischer et al., 1993) were used. Colony hybridization using Hybond-N nylon filters (Amersham) was performed for screening the genomic libraries. The filters were prepared according to Buluwela et al. (1989) for the hybridization procedure.

Hybridization. Chromosomal DNA of C. acetobutylicum was digested to completion with the appropriate restriction enzymes, separated on $0.8 \%$ agarose gels and transferred to Hybond-N + nylon membranes (Amersham) by capillary transfer in $20 \times \mathrm{SSC}(1 \times \mathrm{SSC}$ is $0.15 \mathrm{NaCl}, 15 \mathrm{mM}$ sodium citrate). Prehybridization, probe labelling, hybridization, signal generation and detection were performed according to the instructions of the ECL direct nucleic acid labelling and detection system (Amersham).

Colony hybridization was performed with radiolabelled $([\alpha-$ $\left.{ }^{32} \mathrm{P}\right] \mathrm{dATP}$; Hartmann Analytic) DNA probes. The labelling reaction was performed using the random primer labelling kit (Gibco-BRL Life Technologies), followed by purification of the probe on Sephadex G-25 columns (NAP; Amersham 
Pharmacia Biotech). The filters were prehybridized in $0.2 \%$ $(\mathrm{w} / \mathrm{v})$ polyvinylpyrrolidone, $0 \cdot 2 \%(\mathrm{w} / \mathrm{v})$ Ficoll $400,0 \cdot 2 \%$ $(\mathrm{w} / \mathrm{v}) \mathrm{BSA}, 0 \cdot 1 \%(\mathrm{w} / \mathrm{v})$ sodium pyrophosphate, $10 \%(\mathrm{w} / \mathrm{v})$ dextran sulfate, $1 \mathrm{M} \mathrm{NaCl}, 1 \%$ (w/v) SDS and $50 \mathrm{mM}$ Tris $/ \mathrm{HCl}(\mathrm{pH} 7.5)$ for at least $0.5 \mathrm{~h}$ at $55^{\circ} \mathrm{C}$. After addition of the denaturated, radiolabelled probe, hybridization was continued for $8-12 \mathrm{~h}$. Filters were then washed twice in $2 \times \mathrm{SSC}$ and subjected to autoradiography.

DNA sequencing and sequence analysis. A SequiTherm cycle sequencing kit for LI-COR 4000L (Biozym Diagnostik) and IRD41-labelled primers (MWG Biotech) were used for nonradioactive sequencing. The dideoxy-terminated fragments were separated on $41 \mathrm{~cm}$ long, $6 \%$ polyacrylamide gels or $66 \mathrm{~cm}$ long, $4.3 \%$ polyacrylamide gels (thickness $0.25 \mathrm{~mm}$ ) with a LI-COR model 4000L sequencer (MWG Biotech) as instructed by the manufacturer. Data collection and analysis were performed by the programs BASE IMAGIR Data Collection (version 2.31) and BASE IMAGIR Image Analysis (version 2.3).

Nucleotide and deduced amino acid sequences were analysed by using the GeneWorks (IntelliGenetics) program on a Power Macintosh 8500/120 computer (Apple). Additional analysis was carried out on a UNIX computer, using the Genetics Computer Group sequence analysis software package (version 9.0).

\section{RESULTS}

\section{Enzyme purification and characterization}

The $\mathrm{NAD}^{+}$-dependent GAPDH was purified about 56fold from acid-producing $C$. acetobutylicum cells using a procedure involving a two-step ammonium sulfate precipitation, gel filtration and anion-exchange chromatography. Results of the purification procedure are summarized in Table 1 . The specific activity of the enzyme after anion-exchange chromatography was $27 \mathrm{U}$ $\mathrm{mg}^{-1}$. Dye-ligand chromatography on Reactive Blue 72 as last polishing step resulted in a loss of about $80 \%$ of the enzyme activity. Characterization was therefore carried out with the desalted anion chromatography pool.

SDS-PAGE experiments revealed one type of subunit with a relative molecular mass of $40 \mathrm{kDa}$ (Fig. 1). The $M_{r}$ of native GAPDH was determined by nondenaturing gradient PAGE. Analysis of three separate runs gave an

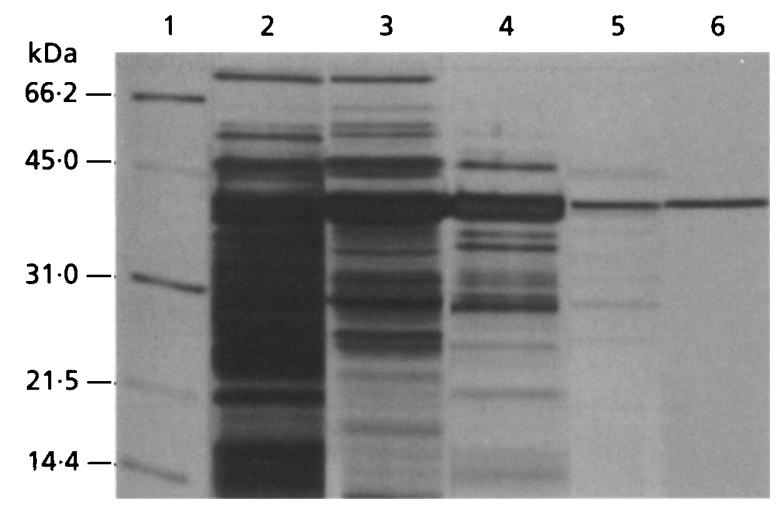

Fig. 1. SDS-PAGE of samples from the purification steps of GAPDH from $C$. acetobutylicum DSM 792. The proteins were separated on a $12 \%$ acrylamide gel. Lanes: 1 , standard proteins (see Methods) with molecular masses on the left; 2, crude extract; 3, ammonium sulfate precipitate; 4, Superdex 200 pool; 5, Q-Sepharose pool; 6, Reactive Blue 72 pool.

avarage $M_{r}$ of 160000 ( \pm 10000 ; data not shown). In agreement with the structure of many other known $\mathrm{NAD}^{+}$-dependent GAPDHs, the enzyme of C. acetobutylicum thus shows a homotetrameric composition. A $\mathrm{pH}$ activity profile was determined for the physiological direction with glyceraldehyde 3 -phosphate $(1 \mathrm{mM})$ as substrate and overlapping buffer systems in the range $5 \cdot 8-11 \cdot 6$. The polynomial curve showed a maximum at $\mathrm{pH} \mathrm{8.5,} \mathrm{whereas} \mathrm{highest} \mathrm{activity} \mathrm{was} \mathrm{observed} \mathrm{with}$ sodium carbonate buffer at $\mathrm{pH} 9 \cdot 3$. Above $\mathrm{pH} 10$, stability decreased rapidly. The temperature optimum of the enzyme was $50^{\circ} \mathrm{C}$; a further increase resulted in rapid inactivation. Above $65^{\circ} \mathrm{C}$ no activity could be detected. According to the Arrhenius plot, an activation energy of $29 \mathrm{~kJ} \mathrm{~mol}^{-1}$ was calculated in the range $10-50^{\circ} \mathrm{C}$. GAPDHs of various sources are able to use various aliphatic aldehydes as substrates. Since butyraldehyde is an intermediate in the butanol production of C. acetobutylicum, we were interested to determine if the GAPDH is able to use butyraldehyde as substrate. However, in contrast to other GAPDHs (e.g. Fife \& Rikihisa, 1970), the clostridial enzyme was not able to

Table 1. Purification of GAPDH from C. acetobutylicum DSM 792

\begin{tabular}{|lccccc|}
\hline Purification step & $\begin{array}{c}\text { Total } \\
\text { protein } \\
(\mathbf{m g})\end{array}$ & $\begin{array}{c}\text { Total } \\
\text { activity } \\
(\mathbf{U})\end{array}$ & $\begin{array}{c}\text { Specific } \\
\text { activity } \\
\left(\mathbf{U ~ m g}^{-1}\right)\end{array}$ & $\begin{array}{c}\text { Recovery } \\
(\%)\end{array}$ & $\begin{array}{c}\text { Purification } \\
\text { factor }\end{array}$ \\
\hline Crude extract & 1500 & 720 & 0.48 & 100 & 1 \\
Ammonium sulfate & 621 & 518 & $0 \cdot 83$ & 72 & $1 \cdot 7$ \\
$\quad(50-90 \%)$ & 132 & 495 & 3.75 & 69 & $7 \cdot 8$ \\
Superdex 200 & 6.4 & 173 & 27 & 24 & 56 \\
Q-Sepharose & $2 \cdot 5$ & 35 & 14 & 5 & 29 \\
Reactive Blue 72 & & & & & \\
\hline
\end{tabular}



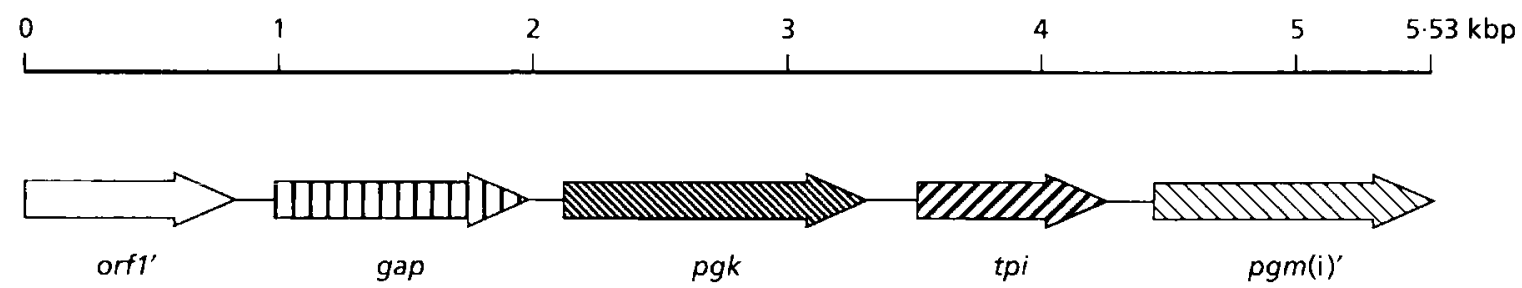

pWS10

pWH19

Fig. 2. Schematic ORF map of the gap gene region in C. acetobutylicum DSM 792. The sequenced part of the insert of pWS10 is shown, as well as the insert of pWH19. Arrows represent length, location and orientation of the genes. A prime at the end of an ORF indicates truncation.

oxidize butyraldehyde at a significant rate (less than $1 \%$ activity compared to glyceraldehyde 3 -phosphate as substrate).

To investigate possible regulation of the enzyme, specific activities were determined in the acidogenic, and early and late solventogenic stages of a continuous culture of C. acetobutylicum. The respective values were $0.42,0.7$ and $0.43 \mathrm{U} \cdot \mathrm{mg}^{-1}$ protein, indicating a low level of regulation at the most.

\section{Cloning and sequencing of the gap gene region from C. acetobutylicum}

Based on the close relationship of C. acetobutylicum to C. pasteurianum, chromosomal DNA of C. pasteurianum was used to generate a $0.9 \mathrm{kbp}$ probe via PCR encoding the main part of the gap gene. Southern hybridization with this heterologous probe showed positive signals with differently digested chromosomal DNA of C. acetobutylicum (data not shown). Two genomic libraries were therefore screened and several positive clones were detected. Two clones were sequenced, one ( $\mathrm{pWH} 19$ ) obtained from the HindIII genomic library and the other (pWS10) from the partially digested Sau3AI genomic library. Fig. 2 shows a schematic map of the gap gene cluster. The gap gene region of $C$. acetobutylicum includes three complete and two incomplete ORFs, all being transcribed in the same direction. The $\mathrm{G}+\mathrm{C}$ content of the genes varies between 34 and $35.5 \mathrm{~mol} \%$.

From the first ORF (orf1') $831 \mathrm{bp}$ were sequenced. Computer alignments (Table 2) of the deduced amino acid sequence revealed significant homology to the Cterminal part of hypothetical proteins of Bacillus megaterium (Urf1), Bacillus subtilis (YvbQ) and Lactobacillus delbrueckii (YgaP), which are also located upstream of their gap genes. The second ORF, encoding a protein of 334 amino acids and a deduced molecular mass of $35.8 \mathrm{kDa}$, was located $145 \mathrm{bp}$ downstream of orf $1^{\prime}$. Because of the high level of similarity of the deduced protein to $\mathrm{NAD}^{+}$-dependent GAPDHs of a variety of organisms and especially to the protein of $C$. pasteurianum (95\% identity; Table 2 ), the respective gene was designated gap. A putative Shine-Dalgarno sequence $\left(5^{\prime}\right.$-TGGAGG-3') was located 8 bp upstream of the methionine start codon. Separated by $136 \mathrm{bp}$, a third ORF of $1194 \mathrm{bp}$ was identified downstream of the gap gene. The deduced protein comprised 397 amino acids $(42.3 \mathrm{kDa})$. A computer search revealed high level similarity between this gene product and those of various phosphoglycerate kinases (PGKs) (Table 2). The gene, designated $p g k$, is preceded by a putative ShineDalgarno sequence $\left(5^{\prime}-\mathrm{ATGAGG}-3^{\prime}\right) 8$ bp upstream of the start codon. Another ORF was located $198 \mathrm{bp}$ downstream of $p g k$. Its predicted amino acid sequence, encoding a protein of 248 amino acids and a molecular mass of $26.5 \mathrm{kDa}$, showed high similarity to another glycolytic enzyme, triosephosphate isomerase (TPI) (Table 2). The respective gene was therefore designated tpi. Eight base pairs upstream of tpi, a putative Shine-Dalgarno sequence (5'-AGGAGT-3') was located. Further sequencing revealed a fifth ORF, located $188 \mathrm{bp}$ downstream of tpi. Amino acid comparison showed high similarities of the respective gene product with the $\mathrm{N}$-terminal region of members of the subclass of phosphoglycerate mutase (PGM) 2,3-bisphosphoglycerate-independent phosphoglycerate mutase [PGM(i)] (Table 2). A putative Shine-Dalgarno se-

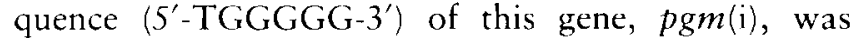
identified 8 bp upstream of the methionine start codon.

In the intergenic regions no typical rho-independent terminator structures could be identified, suggesting a common transcriptional unit comprising cither at least these five genes or rho-dependent termination mechanisms (Platt, 1986). Nucleotide analysis with the programs Stemloop and FoldRNA (Zuker, 1989) revealed only secondary structures with comparatively 
Table 2. Amino acid identity and similarity of the glycolytic proteins and Orf1' from C. acetobutylicum to corresponding proteins of other organisms

\begin{tabular}{|c|c|c|c|c|}
\hline Organism & Protein & $\begin{array}{l}\text { Identity } \\
\qquad \%)\end{array}$ & $\begin{array}{c}\text { Similarity } \\
(\%)\end{array}$ & Reference $^{*}$ \\
\hline \multicolumn{5}{|l|}{ Orf1 $1^{\prime}$} \\
\hline B. megaterium & Urf1 & 38 & 54 & 1 \\
\hline B. subtilis & YvbQ & 38 & 52 & 2 \\
\hline L. delbrueckii & YgaP & 30 & 41 & 3 \\
\hline \multicolumn{5}{|l|}{ GAPDH } \\
\hline C. pasteurianum & GAPDH & 95 & 96 & 4 \\
\hline S. pyogenes & GAPDH & 72 & 78 & 5 \\
\hline L. lactis subsp. lactis & GAPDH & 68 & 74 & 6 \\
\hline E. coli & GAPDH & 59 & 71 & 7 \\
\hline B. subtilis & GAPDH & 56 & 65 & 8 \\
\hline S. cerevisiae & GAPDH & 47 & 57 & 9 \\
\hline \multicolumn{5}{|l|}{ PGK } \\
\hline T. maritima & PGK & 62 & 72 & 10 \\
\hline B. stearothermophilus & PGK & 60 & 68 & 11 \\
\hline N. tabacum & PGKY & 59 & 67 & 12 \\
\hline S. cerevisiae & PGK & 53 & 62 & 13 \\
\hline C. glutamicum & PGK & 48 & 59 & 14 \\
\hline E. coli & PGK & 46 & 55 & 15 \\
\hline \multicolumn{5}{|l|}{ TPI } \\
\hline B. subtilis & TPI & 60 & 67 & 16 \\
\hline L. lactis subsp. lactis & TPI & 59 & 66 & 17 \\
\hline B. stearothermophilus & TPI & 54 & 63 & 18 \\
\hline T. maritima & TPI & 52 & 60 & 10 \\
\hline C. glutamicum & TPI & 46 & 55 & 14 \\
\hline E. coli & TPI & 45 & 53 & 19 \\
\hline S. cerevisiae & TPI & 42 & 51 & 20 \\
\hline \multicolumn{5}{|l|}{$\operatorname{PGM}(\mathrm{i})$} \\
\hline B. subtilis & $\operatorname{PGM}(\mathrm{i})$ & 59 & 65 & 16 \\
\hline B. megaterium & PGM(i) & 59 & 65 & 1 \\
\hline E. coli & $\operatorname{PGM}(\mathrm{i})$ & 53 & 62 & 21 \\
\hline
\end{tabular}

*1, Schläpfer \& Zuber (1992); 2, Kunst et al. (1997); 3, Branny et al. (1998); 4, GenBank accession number Q59309; 5, Lottenberg et al. (1992); 6, Cancilla et al. (1995b); 7, Branlant \& Branlant (1985); 8, Viaene \& Dhaese (1989); 9, Holland et al. (1983); 10, Schurig et al. (1995); 11, Davies et al. (1991); 12, Rao et al. (1995); 13, Hitzeman et al. (1982); 14, Alefounder \& Perham (1989); 15, Eikmanns (1992); 16, Leyva-Vazquez \& Setlow (1994); 17, Cancilla et al. (1995a); 18, Rentier-Delrue et al. (1993); 19, Pichersky et al. (1984); 20, Alber \& Kawasaki (1982); 21, Sofia et al. (1994).

low energy values. The hairpin with the highest energy value (approx. $-20.6 \mathrm{~kJ} \mathrm{~mol}^{-1}$ ) was located downstream of the gap gene.

\section{Conserved functional and structural domains of the glycolytic genes of $C$. acetobutylicum}

The results of alignments of the deduced amino acid sequences of gap, $p g k, t p i$ and $p g m(\mathrm{i})$ of C. acetobutylicum with the respective gene products of other organisms (Gram-positive and Gram-negative prokaryotes and eukaryotes) are summarized in Table 2. As expected, a comparison of GAPDH of C. acetobutylicum revealed high similarity values $(95 \%)$ to the closely related C. pasteurianum. Significant homology was also observed with GAPDHs of streptococcal origin (Lottenberg et al., 1992). Even enzymes from eukaryotic organisms showed relatively high homology values. Several regions with important catalytic or structural functions are conserved in all sequences, i.e. residues which are involved in forming and stabilizing the nucleotide-binding site (residues 3-18, especially Asn-7, Arg-11, Ile-12, Asn-32, Asp-47, Glu-76, Glu-94, Thr-96, His-108 and Glu-315 in the C. acetobutylicum sequence), in forming and function of the binding site for inorganic phosphate (Ser-151, Cys-152 and Thr-153), or in other catalytically important residues such as His-180 (Biesecker et al., 1977; Duée et al., 1996; Moras et al., 1975; Skarzynski et al., 1987; Soukri et al., 1989). A less conserved region is the so-called S-loop, which is 
responsible for building the tetrameric structure of GAPDH (residues 182-206).

The mostly monomeric enzyme PGK is also highly conserved among pro- and eukaryotic organisms. The degree of identity of the clostridial enzyme to other PGKs varies between $46 \%$ (E. coli) and $62 \%$ for the PGK part of the PGK-TPI fusion protein of the hyperthermophilic Thermotoga maritima (Schurig et al., 1995). In addition, eukaryotic enzymes such as PGKY from Nicotiana tabacum show a comparatively high identity of $59 \%$. Taking into account the results of crystal structure and mutant analysis of pro- and eukaryotic organisms, several conserved sequence regions and certain amino acids which are important for the structure and the catalytic mechanism of PGK (Banks et al., 1979; Davies et al., 1993; Fairbrother et al., 1989; Watson et al., 1982) were identified. The PGK of C. acetobutylicum also shows the highly conserved residues His-61 and Arg-154 and, in the C-terminal region, amino acids $373-378$, which are involved in substrate binding. Arg-64, which is conserved in most sequences, is replaced in the clostridial enzyme by another basic amino acid, lysine. ADP-binding regions could be identified in the C. acetobutylicum gene product (residues 198-202, 220-224, 297-298, 319-327 and 352-355, especially Lys-205, Leu-297, Glu-327 and Asp-355). His61, Arg-154 and His-156 are the counterpart residues in C. acetobutylicum which are essential for conformational change of PGK during catalysis (Fairbrother $e t$ al., 1989).

TPI is also well characterized by various crystal structure and mutant analyses. The degree of identity of the clostridial TPI and other TPIs varies from $60 \%$ (B. subtilis) to $42 \%$ for the eukaryotic yeast enzyme (Table 2 ). The catalytically and structurally important residues Lys-11, His-94, Glu-164-Gly 174 (especially Glu-166), Ile-207, residues 209-212 and Leu-231-Leu-237 are also found in the C. acetobutylicum sequence (Banner et al., 1975; Lolis et al., 1990; Wierenga et al., 1992).

Based on sequence comparison the clostridal PGM was identified as PGM(i). The first PGM(i) was isolated from maize only in 1992 (Graña et al., 1992), explaining the lack of structural information about this enzyme type. A monomeric composition is characteristic for this class of PGMs (Fothergill-Gillmore \& Watson, 1989).

\section{Functional complementation of an E. coli gap mutant}

To determine if the predicted clostridial gap gene really encodes the purified clostridial $\mathrm{NAD}^{+}$-dependent GAPDH, the expression of this gene in the E. coli gap mutant (W3CG) was attempted. This mutant carries a transposon insertion within the gap gene so that no enzyme activity can be measured nor a complete protein be produced. It is therefore only able to grow with succinate or malate as carbon source. Mutant cells harbouring the recombinant plasmid pWH19 with the whole clostridial gap gene and parts of orf $1^{\prime}$ and $p g k$ were able to grow on glucose minimal or LB medium.
Enzyme activities were determined from cell extracts of the mutants and the complemented mutants grown on M63 medium with succinate as carbon source. Activity in C. acetobutylicum $\left[0.5 \mathrm{U} \cdot(\mathrm{mg} \text { protein })^{-1}\right]$ was determined from glucose-grown cultures. Whereas the extracts of W3CG and W3CG harbouring pUC9 showed a specific activity of less than $1 \mathrm{mU} \cdot(\mathrm{mg} \text { protein })^{-1}$, the complemented mutant had a 100 -fold higher activity $\left[110 \mathrm{mU} \cdot(\mathrm{mg} \text { protein })^{-1}\right.$. The data confirmed that pWH19 really contained the clostridial gap gene and that this gene is expressed in the E. coli mutant W3CG.

\section{DISCUSSION}

The data reported describe the purification and enzymic characterization of the $\mathrm{NAD}^{+}$-dependent GAPDH of C. acetobutylicum DSM 792, and cloning and sequencing of the respective gene. Complementation of an E. coli gap mutant, and the similarity of the gene product to homologous enzymes, clearly revealed the identity of the gene.

Interestingly, the clostridial GAPDH seems to be a moderately thermotolerant enzyme with a temperature optimum of $50^{\circ} \mathrm{C}$. This could be explained by a slightly higher portion of structure-stabilizing amino acids such as alanine, arginine, leucine and proline (Rentier-Delrue et al., 1993; Schläpfer \& Zuber, 1992). An increased thermostability is not characteristic for enzymes of the mesophilic C. acetobutylicum. GAPDH does not appear to be significantly regulated during the transition from the acidogenic to the solventogenic stage of C. acetobutylicum. The less than twofold increase in specific activity corresponds nicely to data obtained from twodimensional gel electrophoresis analysis, which also show an about twofold higher abundance of the protein in the early solventogenic stage. However, no increase in synthesis rate could be observed (Schaffer \& Dürre, unpublished results), indicating that no regulation at the transcriptional level occurred, but rather a decrease in protein turnover or denaturation. This again is in accordance with the transient increase in chaperone synthesis at the onset of solventogenesis in C. acetobutylicum (Pich et al., 1990), which also explains the later decrease in the enzymic specific activity to the original level.

The high degree of conservation of the clostridial GAPDH also extends to residues important for $\mathrm{NAD}^{+} / \mathrm{NADH}$ binding. The invariant Asn-313 of $E$. coli is found in C. acetobutylicum at position 314. A change of this amino acid in E. coli to threonine resulted in a drastic decrease in NAD ${ }^{+}$affinity (Duée et al., 1996). Another possible way to influence the cofactor effect on the enzyme could be to induce a mutation at Gly-188 Pro-189 (conserved in E. coli at positions 187 and 188), which determine the specificity of $\mathrm{NAD}^{+}$versus $\mathrm{NADP}^{+}$. A change of the proline to a serine in $E$. coli indeed allowed the enzyme to use $\mathrm{NADP}^{+}$as a coenzyme (Duée et al., 1996).

The GAPDH of C. acetobutylicum shows high homology $(72-78 \%, S$. pyogenes, Table 2$)$ to members of 
this enzyme class that are characterized by additional physiological functions, i.e. adhesion to fibronectin, myosin and actin or a function as plasmin receptor on the cell surface or a role in ADP ribosylation (Lottenberg et al., 1992; Pancholi \& Fischetti, 1993). Eukaryotic GAPDHs are also involved in several processes such as endocytosis, DNA repair, tRNA export, programmed death of neurons, etc. (Sirover, 1997). This indicates that GAPDH might possess other functions in addition to its role in energy metabolism.

Nothing is known about the function of the ORF preceding the glycolytic genes in several bacteria (Table 2). It was first detected in B. megaterium (Schläpfer \& Zuber, 1992), but there is no unequivocal evidence for its expression. For the corresponding gene in $\mathrm{L}$. delbrueckii it was suggested that it is part of an operon localized directly upstream of the gap-pgk-tpi operon (Branny et al., 1998). Codon usage analysis of Orf1' shows a much weaker bias compared to the following glycolytic genes, indicating a weaker expression of the putative protein in C. acetobutylicum.

Sequence analysis of the incomplete ORF located at the 3'-terminus of the insert revealed high homology to PGM(i)s. Whilst most PGMs show a clear cofactor dependence on bisphosphoglycerate and a monomeric, dimeric or trimeric structure with subunit molecular masses of $23-30 \mathrm{kDa}$, this newly identified subclass of PGM is characterized by a monomeric structure with a molecular mass of approximately $60 \mathrm{kDa}$ and these enzymes do not show a dependence on bisphosphoglycerate (Fothergill-Gillmore \& Watson, 1989). Interestingly, the well-characterized PGM(i) of $B . s u b$ tilis has an absolute requirement for $\mathrm{Mn}^{2+}$, which is responsible for the extreme sensitivity of the enzyme to $\mathrm{pH}$ variations: lowering of $\mathrm{pH}$ values results in the inactivation of PGM (Kuhn et al., 1993). This feature of PGM enables the forespore to accumulate 3-phosphoglycerate as an energy storage compound since sporulation is accompanied by a slow decrease in $\mathrm{pH}$. As realkalinization is one of the first reactions during germination, PGM is partly reactivated and 3-phosphoglycerate can be reutilized within the very first minutes of germination (Kuhn et al., 1993). Clostridia also accumulate 3-phosphoglycerate in late phases of sporulation (Loshon \& Setlow, 1994) and it is likely that the PGM(i) of C. acetobutylicum is also $\mathrm{Mn}^{2+}$-dependent and plays an important role in accumulating energy resources for germination. It remains to be shown if a decrease in PGM activity in C. acetobutylicum takes place upon induction of sporulation or solvent formation, which are accompanied by a decrease in $\mathrm{pH}$.

Organization of glycolytic pathway genes in bacteria is characterized by a high degree of variability. Whereas in some bacteria, for example L. lactis (Cancilla et al., 1995a, b), genes like gap or tpi are not clustered with those of other enzymes of the glycolytic pathway, others show one or more glycolytic genes in the adjacent regions. In E. coli, gapA and $t p i$ are not clustered with other genes of the pathway (Branlant \& Branlant, 1985;
Berlyn, 1998), but $p g k, f d a$ (fructose 1,6-bisphosphate aldolase gene) and gapB (erythrose-4-phosphate dehydrogenase) are (Alefounder \& Perham, 1989). A bicistronic gap-pgk operon exists in Zymomonas mobilis (Eddy et al., 1989), whereas in Corynebacterium glutamicum, Borrelia burgdorferi and Lactobacillus delbrueckii a cluster of gap-pgk-tpi was detected (Eikmanns, 1992; Gebbia et al., 1997; Branny et al., 1998). Exactly the same arrangement of glycolytic genes as in C. acetobutylicum, including or $11^{\prime}$, was found in $B$. subtilis and B. megaterium (Kunst et al., 1997; Schläpfer \& Zuber, 1992). The glycolytic gene cluster of B. subtilis contains additionally the gene for the enolase (eno) downstream of $\operatorname{pgm}(\mathrm{i})$. The possibility that the clostridial gene cluster also contains an additional glycolytic gene downstream of $p g m(i)$ cannot be ruled out. Computer analysis revealed no rho-independent terminator structures in this region. Future experiments will aim at a detailed transcript analysis of this region in C. acetobutylicum.

\section{ACKNOWLEDGEMENTS}

We thank A. Plückthun for providing the E. coli gap mutant W3CG and B. Zickner for technical assistance. This work was supported by a grant from the Deutsche Forschungsgemeinschaft.

\section{REFERENCES}

Alber, T. \& Kawasaki, G. (1982). Nucleotide sequence of the triose phosphate isomerase gene of Saccharomyces cerevisiae. J Mol Appl Genet 1, 419-434.

Alefounder, P. R. \& Perham, R. N. (1989). Identification, molecular cloning, and sequence analy sis of a gene cluster encoding the class II fructose 1,6-bisphosphate aldolase, 3-phosphoglycerate kinase and a putative second glyceraldehyde 3-phosphate dehydrogenase of Escherichia coli. Mol Microbiol 3, 723-732.

Bahl, H., Andersch, W. \& Gottschalk, G. (1982). Continuous production of acetone and butanol by Clostridium acetobutylicum in a two-stage phosphate limited chemostat. Eur J Appl Microbiol Biotechnol 15, 201-205 (Erratum 17, 73, 1983).

Banks, R. D., Blake, C. C. F., Evans, P. R., Haser, R., Rice, D. W., Hardy, G. W., Merrett, M. \& Phillips, A. W. (1979). Sequence, structure and activity of phosphoglycerate kinase: a possible hinge-bending enzyme. Nature 279, 773-777.

Banner, D. W., Blommer, A. C., Petsko, G. A. \& 9 other authors (1975). Structure of chicken muscle triose phosphate isomerase determined crystallographically at $2.5 \AA$ resolution using amino acid sequence data. Nature 255, 609-617.

Belouski, E., Watson, D. E. \& Bennett, G. N. (1998). Cloning, sequence, and expression of the phosphofructokinase gene of Clostridium acetobutylicum ATCC 824 in Escherichia coli. Curr Microbiol 37, 17-22.

Berlyn, M. K. B. (1998). Linkage map of Escherichia coli K-12, edition 10: the traditional map. Microbiol Mol Biol Rev 62, 814-984.

Bertram, J. \& Durre, P. (1989). Conjugal transfer and expression of streptococcal transposons in Clostridium acetobutylicum. Arch Microbiol 151, 551-557.

Biesecker, G., Harris, J. I., Thierry, J. C., Walker, J. E. \& Wonacott, A. J. (1977). Sequence and structure of glyceraldehyde-3-phos- 
phate dehydrogenase from Bacillus stearothermophilus. Nature 266, 328-333.

Blum, H., Beier, H. \& Gross, H. J. (1987). Improved silver staining of plant proteins, RNA and DNA in polyacrylamide gels. Electrophoresis 8, 93-99.

Bradford, M. M. (1976). A rapid and sensitive method for the quantitation of microgram quantities of protein utilizing the principle of protein-dye binding. Anal Biochem 72, 248-254.

Branlant, G. \& Branlant, C. (1985). Nucleotide sequence of the Escherichia coli gap gene. Different evolutionary behavior of the $\mathrm{NAD}^{+}$-binding domain and of the catalytic domain of $\mathrm{D}$ glyceraldehyde-3-phosphate dehydrogenase. Eur J Biochem 150, $61-66$.

Branny, P., de la Torre, F. \& Garel, J.-R. (1998). An operon encoding three glycolytic enzymes in Lactobacillus delbrueckii subsp. bulgaricus: glyceraldehyde-3-phosphate dehydrogenase, phosphoglycerate kinase and triosephosphate isomerase. Microbiology 144, 905-914.

Buluwela, L., Förster, A., Boehm, T. \& Rabbits, T. H. (1989). A rapid procedure for colony screening using nylon filters. Nucleic Acids Res 17, 452

Cancilla, M. R., Davidson, B. E., Hillier, A. J., Nguyen, N. Y. \& Thompson, J. (1995a). The Lactococcus lactis triosephosphate isomerase gene, $t p i$, is monocistronic. Microbiology 141, 229-238.

Cancilla, M. R., Hillier, A. J. \& Davidson, B. E. (1995b). Lactococcus lactis glyceraldehyde-3-phosphate dehydrogenase gene, gap: further evidence for strongly biased codon usage in glycolytic pathway genes. Microbiology 141, 1027-1036.

Davies, G. J., Littlechild, J. A., Watson, H. C. \& Hall, L. (1991). Sequence and expression of the gene encoding 3-phosphoglycerate kinase from Bacillus stearothermophilus. Gene 109, 39-45.

Davies, G. J., Gamblin, S. J., Littlechild, J. A. \& Watson, H. C. (1993). The structure of a thermally stable 3-phosphoglycerate kinase and a comparison with its mesophilic equivalents. Proteins $15,283-289$.

Duée, E., Olivier-Deyris, L., Fanchon, E., Corbier, C., Branlant, G. \& Dideberg, O. (1996). Comparison of the structure of wild-type and a N313T mutant of Escherichia coli glyceraldehyde-3phosphate dehydrogenase: implication for NAD binding and cooperativity. J Mol Biol 25, 814-838.

Dürre, P. (1998). New insights and novel developments in clostridial acetone/butanol/isopropanol fermentation. Appl Microbiol Biotechnol 49, 639-648.

Eddy, C. K., Mejia, J. P., Conway, T. \& Ingram, L. O. (1989). Differential expression of gap and $p g k$ genes within the gap operon of Zymomonas mobilis. J Bacteriol 171, 6549-6554.

Eikmanns, B. J. (1992). Identification, sequence analysis, and expression of a Corynebacterium glutamicum gene cluster encoding the three glycolytic enzymes glyceraldehyde-3-phosphate dehydrogenase, 3-phosphoglycerate kinase, and triosephosphate isomerase. J Bacteriol 174, 6076-6086.

Fairbrother, W. J., Walker, P. A., Minard, P., Littlechild, J. A., Watson, H. C. \& Williams, R. J. P. (1989). NMR analysis of sitespecific mutants of yeast phosphoglycerate kinase. Eur J Biochem $183,57-67$

Fife, T. H. \& Rikihisa, T. (1970). Reaction of glyceraldehyde 3phosphate dehydrogenase with aliphatic aldehydes. Biochemistry 9, 4064-4067.

Fischer, R.-J., Helms, J. \& Dürre, P. (1993). Cloning, sequencing, and molecular analysis of the sol operon of Clostridium acetobutylicum, a chromosomal locus involved in solventogenesis. J Bacteriol 175, 6959-6969.
Fothergill-Gillmore, L. A. \& Watson, H. C. (1989). The phosphoglycerate mutases. Adv Enzymol 62, 227-313.

Ganter, C. \& Plückthun, A. (1990). Glycine to alanine substitutions in helices of glyceraldehyde-3-phosphate dehydrogenase: effects on stability. Biochemistry 29, 9395-9402.

Gebbia, J. A., Backenson, P. B., Coleman, J. L., Anda, P. \& Benach, J. L. (1997). Glycolytic enzyme operon of Borrelia burgdorferi: characterization and evolutionary implications. Gene 188, 221-228.

Girbal, L. \& Soucaille, P. (1994). Regulation of Clostridium acetobutylicum metabolism as revealed by mixed-substrate steady-state continuous culture: role of NADH/NAD ratio and ATP pool. J Bacteriol 176, 6433-6438.

Graña, X., de Lecea, L., El-Maghrabi, R., Ureña, J., Caellas, C., Carreras, J., Puigdomènech, P., Pilkis, S. \& Climent, F. (1992). Cloning and sequencing of cDNA encoding 2,3-bisphosphoglycerate-independent phosphoglycerate mutase from maize. J Biol Chem 267, 12797-12803.

Hitzeman, R. A., Hagie, F. E., Hayflick, J. S., Chen, C. Y., Seeburg, P. H. \& Derynck, R. (1982). The primary structure of Saccharomyces cerevisiae gene for 3-phosphoglycerate kinase. Nucleic Acids Res 10, 7791-7808.

Holland, J. P., Labieniec, L., Swimmer, C. \& Holland, M. J. (1983). Homologous nucleotide sequences at the $5^{\prime}$ termini of messenger RNAs synthesized from the yeast enolase and glyceraldehyde-3phosphate dehydrogenase gene families. The primary structure of a third yeast glyceraldehyde-3-phosphate dehydrogenase gene. J Biol Chem 258, 5291-5299.

Jones, D. T. \& Woods, D. R. (1986). Acetone-butanol fermentation revisited. Microbiol Rev 50, 484-524.

Kuhn, N. J., Setlow, B. \& Setlow, P. (1993). Manganese(II) activation of 3-phosphoglycerate mutase of Bacillus megaterium: $\mathrm{pH}$-sensitive interconversion of active and inactive forms. Arch Biochem Biophys 306, 342-349.

Kunst, F., Ogasawara, N., Moszer, I. \& 148 other authors (1997). The complete genome sequence of the gram-positive bacterium Bacillus subtilis. Nature 390, 249-256.

Laemmli, U. K. (1970). Cleavage of structural proteins during the assembly of the head of bacteriophage T4. Nature 227, 680-685.

Leyva-Vazquez, M. A. \& Setlow, P. (1994). Cloning and nucleotide sequences of the genes encoding triose phosphate isomerase, phosphoglycerate mutase, and enolase from Bacillus subtilis. J Bacteriol 176, 3903-3910.

Lolis, E., Alber, T., Davenport, R. C., Rose, D., Hartman, F. C. \& Petsko, G. A. (1990). Structure of yeast triosephosphate isomerase at 1.9-A resolution. Biochemistry 29, 6609-6618.

Loshon, C. A. \& Setlow, P. (1994). Levels of small molecules in dormant spores of Sporosarcina species and comparison with levels in spores of Bacillus and Clostridium species. Can J Microbiol 39, 259-262.

Lottenberg, R., Broder, C. C., Boyle, M. D., Kain, S. J., Schroeder, B. L. \& Curtiss, R. (1992). Cloning, sequence analysis, and expression in Escherichia coli of a streptococcal plasmin receptor. J Bacteriol 174, 5204-5210.

Lovitt, R. W., Chen, G. J. \& Zeikus, J. G. (1988). Ethanol production by thermophilic bacteria: biochemical basis for ethanol and hydrogen tolerance in Clostridium thermobydrosulfuricum. J Bacteriol 170, 2809-2815.

Moras, D., Olsen, K. W., Sabesan, M. N., Buehner, M., Ford, G. C. \& Rossmann, M. G. (1975). Studies of asymmetry in the threedimensional structure of lobster D-glyceraldehyde-3-phosphate dehydrogenase. J Biol Chem 250, 9137-9162. 
O'Brien, R. W. \& Morris, J. G. (1971). Oxygen and the growth and metabolism of Clostridium acetobutylicum. J Gen Microbiol 68, 307-318.

Pancholi, V. \& Fischetti, V. A. (1993). Glyceraldehyde-3-phosphate dehydrogenase on the surface of group A streptococci is also an ADP-ribosylating enzyme. Proc Natl Acad SciUSA 90, 8154-8158.

Pich, A., Narberhaus, F. \& Bahl, H. (1990). Induction of heat shock proteins during initiation of solvent formation in Clostridium acetobutylicum. Appl Microbiol Biotechnol 33, 697-704.

Pichersky, E., Gottlieb, L. D. \& Hess, J. F. (1984). Nucleotide sequence of the triosephosphate isomerase gene of Escherichia coli. Mol Gen Genet 195, 314-320.

Platt, T. (1986). Transcription termination and the regulation of gene expression. Annu Rev Biochem 55, 339-372.

Rao, S. K., Bringloe, D. H., Dyer, T. A., Raines, C. A. \& Bradbeer, J. W. (1995). Nucleotide sequences of cDNAs encoding the chloroplastic and cytosolic phosphoglycerate kinases (accession nos. Z48976 and Z48977) from tobacco. Plant Physiol 109, 1126.

Rentier-Delrue, F., Mande, S. C., Moyens, S., Terpstra, P., Mainfroid, V., Goraj, K., Lion, M., Hol, W. G. \& Martial, J. A. (1993). Cloning and overexpression of the triosephosphate isomerase genes from psychrophilic and thermophilic bacteria. Structural comparison of the predicted protein sequences. $J$ Mol Biol 229, 85-93.

Sambrook, J., Fritsch, E. F. \& Maniatis, T. (1989). Molecular Cloning: a Laboratory Manual, 2nd edn. Cold Spring Harbor, NY: Cold Spring Harbor Laboratory.

Sauer, U., Treuner, A., Buchholz, M., Santangelo, J. D. \& Durre, P. (1994). Sporulation and primary sigma factor homologous genes in Clostridium acetobutylicum. J Bacteriol 176, 6572-6582.

Schlapfer, B. S. \& Zuber, H. (1992). Cloning and sequencing of the genes encoding glyceraldehyde-3-phosphate dehydrogenase, phosphoglycerate kinase and triosephosphate isomerase (gap operon) from the mesophilic Bacillus megaterium: comparison with corresponding sequences from thermophilic Bacillus stearothermophilus. Gene 122, 53-62.

Schurig, H., Beaucamp, N., Ostendorp, R., Jaenicke, R., Adler, E. \& Knowles, J. R. (1995). Phosphoglycerate kinase and triosephosphate isomerase from the hyperthermophilic bacterium
Thermotoga maritima form a covalent bifunctional enzyme complex. EMBO J 14, 442-451.

Silhavy, T. J., German, M. L. \& Enquist, L. W. (1984). Experiments with Gene Fusions. Cold Spring Harbor, NY: Cold Spring Harbor Laboratory.

Sirover, M. A. (1997). Role of glycolytic protein, glyceraldehyde3 -phosphate dehydrogenase, in normal cell function and in cell pathology. J Cell Biochem 66, 133-140.

Skarzynski, T., Moody, P. C. E. \& Wonacott, A. J. (1987). Structure of holo-glyceraldehyde-3-phosphate dehydrogenase from Bacillus stearothermophilus at 1.8 $\AA$ resolution. J Mol Biol 193, 171-187.

Sofia, H. J., Burland, V., Daniels, D. L., Plunkett, G. \& Blattner, F. R. (1994). Analysis of the Escherichia coli genome. V. DNA sequence of the region from 76.0 to 81.5 minutes. Nucleic Acids Res 22, 2576-2586.

Soukri, A., Mougin, A., Corbier, C., Wonacott, A., Branlant, C. \& Branlant, G. (1989). Role of the histidine 176 residue in glyceraldehyde-3-phosphate dehydrogenase as probed by site-directed mutagenesis. Biochemistry 28, 2586-2592.

Treuner-Lange, A., Kuhn, A. \& Dürre, P. (1997). The $k d p$ system of Clostridium acetobutylicum: cloning, sequencing, and transcriptional regulation in response to potassium concentration. $J$ Bacteriol 179, 4501-4512.

Viaene, A. \& Dhaese, P. (1989). Sequence of the glyceraldehyde-3phosphate dehydrogenase gene from Bacillus subtilis. Nucleic Acids Res 17, 1251.

Watson, H. C., Walker, N. P. C., Shaw, P. J. \& 9 other authors (1982). Sequence and structure of yeast phosphoglycerate kinase. EMBO J 1, 1635-1640.

Wierenga, R. K., Noble, M. E. M. \& Davenport, R. C. (1992). Comparison of the refined crystal structures of liganded and unliganded chicken, yeast and trypanosomal triosephosphate isomerase. J Mol Biol 224, 1115-1126.

Zuker, M. (1989). Computer prediction of RNA structure. Methods Enzymol 180, 262-288.

Received 23 December 1998; revised 10 March 1999; accepted 9 April 1999. 